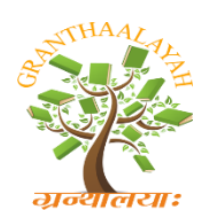

INTERNATIONAL JOURNAL OF RESEARCH GRANTHAALAYAH A knowledge Repository

Social

\title{
RAJA RAO'S KANTHAPURA AS THE MICROCOSM OF THE INDIAN ETHOS AND CULTURE EMBODIED IN A TALE FOR FREEDOM FROM FOREIGN RULE
}

\author{
Dr. Gopal Sinha *1 \\ ${ }^{* 1}$ Assistant Professor of English, Tilka Manjhi Bhagalpur University, Bhagalpur, India
}

DOI: https://doi.org/10.29121/granthaalayah.v5.i6.2017.2043

\begin{abstract}
'Kanthapura' is a Gandhian saga which appears more as a 'sthala-purana'. It is dominated by the place and not by the people. Raja Rao has not created any heores or heroines in this novel. It is not the story of the actions of any hero or god or goddess. It is the story of the actions of the entire village. The novel deals with its topography, its products, its myths and legends, its religion and society and its caste-ridden people. It describes the impact of the Gandhian freedom movement on this tiny village, its unequal fight against the forces of British imperialism and the sufferings of the people. The end of the novel sees the end of this village. There is an exodus of the survivors to Kashipura. The village rose as one man against foreign rule and was temporarily defeated. The village houses were destroyed. But the spirit that was generated was undying and ultimately resulted in complete independence of the country.
\end{abstract}

Keywords: Kanthapura; Raja Rao; Tale; Freedom from Foreign Rule.

Cite This Article: Dr. Gopal Sinha. (2017). "RAJA RAO'S KANTHAPURA AS THE MICROCOSM OF THE INDIAN ETHOS AND CULTURE EMBODIED IN A TALE FOR FREEDOM FROM FOREIGN RULE." International Journal of Research - Granthaalayah, 5(6), 362-367. https://doi.org/10.29121/granthaalayah.v5.i6.2017.2043.

\section{Introduction}

The novelist begins by describing the village and its people. The village is situated on the Western Ghats in the province of Kara. The land is rich and a lot of coffee, cardamom and sugarcane are produced in the area. But the people are poor because the plantations are owned by foreigners or rich Indian businessmen who exploit the people and send the produce to foreign countries. The society of Kanthapura was caste ridden. In the small village there was a Brahmin quarter, a weavers' quarter, a potters' quarter, a sudra quarter. The temple was the nerve centre of the village. Moorthy, who had come to the village after giving up his studies under Gandhiji's influence, found a linga in a backyard. All the boys who were in the village during the vacation 
cooperated in building the temple. The boys started organizing various festivals, harikathas and bhajans in the temple. One harikatha completely changed the life of the village.

The main plot of the novel is concerned with the impact of the Gandhian movement on the people of Kanthapura. The sub-plot deals with the sufferings of the poor workers in the Skeffington Coffee Estate near Kanthapura. The overall impression created on our minds is that of the stark poverty of the people and exploitation of the Indian masses by the Britishers and atrocities committed on unarmed Satyagrahis by by the Government. We admire the bravery of the villagers and coolies who remain non-violent in spite of the worst violence unleased on them by the police. They suffered untold hardships and lost everything they had but did not lose faith in the principles and policies of Mahatma Gandhi. Their unflinching faith in God sustained them through all their sufferings.

The theme of the novel is purely Indian. It is the impact of the country-wide freedom movement on this village. Raja Rao tells us how the people of Kanthapura, with one or two exceptions, adopted and practiced the principles of Mahatma Gandhi. Gandhiji was a deeply religious man. He believed in loving even the enemy and changing his heart by suffering in silence. For the people of Kanthapura also the fight against became a religious duty. Moothy practiced himself and taught others that real love was the love of humanity. They truly practiced non-violence. They did not raise their head. When Bade Khan manhandled Moorthy, the wives of the coolies fell upon him and would have killed him, but Moorthy asked them to release him. When the soldiers were firing at the unarmed Satyagrahis and beating the heads of women with their rifle butts, Ratna shouted, "No violence in the name of the Mahatma."(Kanthapura) Untouchability was completely given up in this village. The Brahmins and the pariahs fought against the British shoulder to shoulder. Everybody in this village started plying the charkha. They also practiced Gandhiji's plan of prohibition by picketing toddy booths and toddy shops. And when Mahatma Gandhi started his non-cooperation movement, the people of Kanthapura refused to pay taxes and cheerfully faced lathis and bullets. They lost their near and dear ones; they lost their lands and houses and those who survived had to seek refuge in Kashipura. The clarion call of Gandhi made all of them soldiers and they sacrificed everything for the nation.

Another Indian theme which runs through the novel is that of Shakti-worship. Ordinarily women are shy, delicate and submissive, but when they are inspired by a great ideal they become symbols of Shakti or power. When Gandhiji's ideals inspire the women of Kanthapura, an indomitable spirit possesses them. The satyagraha is now their movement. When Murthy is arrested, Ratna, a young girl becomes their leader and all the women of the village stand behind her like a wall. Fire cannot move them. Bullets cannot break them. They suffer in the name of the Mahatma; they are firm as a rock.

Kanthapura is an Indian novel in the true sense of the term. It is written in the style of an Indian grand-mother telling a story. There are long, meandering sentences and long paragraphs. The style is gossipy, full of digressions. This is the style of the puranas, the Mahabharata and the Ramayana. We tell on interminable tale... episode follows and when our thoughts stop our breath stops, and we move on to another thought. Although the novel is written in English, but the style of writing is entirely Indian. The following prayer to Kenchamma seems to spring from every Indian heart - 
"O Kenchamma! Protect us always like this through famine and disease, death and despair. O most high and bounteous! We shall offer you our first rice and first fruit, and we shall offer you saris and bodice cloth for every birth and marriage, we shall wake thinking of you, sleep prostrating before you, Kenchamma...." (Kanthapura)

Raja Rao's purpose in Kanthapura was to portray a massive movement, not to indivisualize the characters who are summoned to join hands with Moorthy or to oppose him. They are all viewed in relation to Kanthapura and the movement. Kanthapura is not a novel of character in the sense in which Hardy's Tess and Dicken's David Copperfield are. Kanthapura brings a small village in the forefront of the movement. The village is conceived as a character who towers above other characters and, in the final analysis, emerges as the hero of the novel. It is the ebb and fall, the resurgence and ruin of the village that is the central theme of the novel. David McCutchion remarks:

“...psychological motivation and characterization are absent in Kanthapura.”

The novel envisages a thousand-pillared temple in which each individual is a pillar... and the temple is the temple of the one, and we are one with everything that is in the one, and who shall say he is at the head of the one and another at the foot. Brothers...ye shall remember whether Brahmin or bangle-seller, pariah or priest, we are all one, ane as the mustard seed in a sack of mustard seeds, equal in shape and hue and all ..we are yoked to the same plough.." (Kanthapura) In this scheme of universal fraternity, accord, harmony and integration, a pariah and a priest, a Brahmin and a weaver, a Swami and a Sudra jostle with one another in the procession of characters, and there is no room for the exploits of an individual. Prawer Jhabvala remarks:

"...here (in Kanthapura) we(characters) are part of one another and beyond and above that, part of God."

The range of Raja Rao's characterization in Kanthapura is limited to the society of a small village, composed of the Brahmin, the Sudra, the weaver, the potter and the pariah, the betrayer, the honest and the dishonest, the gracious and the odious. The characters can be classified into tow groups: the Pro-Gandhians and the Anti-Gandhians. The Pro-Gandhians include Moorthy, Range, Rangamma, Ratna and a host of their followers in the village, from the Skeffington Coffee Estate and the adjoining village. Among the Anti-Gandhians the prominent characters are Bhatta, Bade Khan, the Swami and Venkamma. The bulk of the characters are from the soil. Then we have the presiding deity Kenchamma and the Mahatma who does not appear on the scene but inspires the people.

Characterization harmonizes well with the theme. There is a massive movement, a small canvas but plenty of characters. Characters form the narrative. There are plenty of portraits or physiognomical studies, despite a great deal of action in the novel. They are drawn from personal observation and with the precision of a painter. They are not allowed to develop their subsidiary traits. They are called upon to respond to the call of Moorthy, to integrate with the greater interests and to sacrifice their hearth and home for the society. They demonstrate, they picket, they defy bans, they organize processions, they face the music of confrontation with the police; they backbite, they quarrel; but they do not vary. They are, invariably, the staunch Satyagrahis or 
the staunch volunteers. Venkamma remains Venkamma, and the carpenter Kenchayya does not saw out her tongue. Bhatta's lust for money is insatiable. He leaves Kanthapura for Kashi where for every hymn and hiccup a rupee is given ( a city of salvation is for him a place for accumulation of wealth).

The characters are distinct from one another. The use of pet names, descriptive names, which a rural habit, helps in distinguishing the characters. After the march of the Satyanarayan procession the Maddur women ask he volunteers about their sons, fathers, husbands... and of Mota who had a scar on the right eye and Chenna who was this much tall and betel-seller, Madayya, you could not mistake him. Characters are endowed with unmistakable identity; they are recognizable even among thousands. Their peculiar habits and manners make them conspicuous: Nanjamma with nose-scratching, Venkamma with a wagging tongue, Bade Khan with his abusive and filthy speech.

The Pro-Gandhians are contrasted with the anti-Gandhians. Individually, they are endowed with contrasting qualities and visions. Venkamma's virulence and meanness are opposed to Rangamma's graciousness, indulgence for the enemy and lofty ideals of disinterested service to society. Ratna, a girl of fifteen years, has qualities that condone roughness of her tongue and contrast her with Venkemma. Advocate Sankar's adherence to Gandhism is in sharp contast to the loose life of Advocate Seenappa. Bhatta is no match to the Brahministic qualities of old Ramkrishanyya. Glaring ambivalence is seen if Bhatta is contrasted with Moorthy. The difference lies in the ends they have proposed for themselves and in the ways they adopt. Moorthy sees himself as a follower of the Mahatma, always inspired by the ideals of Truth, nonviolence, communal harmony, integrity and non-attachment to riches. He regards himself as a pebble, and his aim is to liberate the country and to weld it into a solid body. Set against this is Bhatta's acquisitiveness, duplicity and exclusive religion. Moorthy lives in a much higher world of values than Bhatta's world of greed, connivance and flattery.

Raja Rao seeks to propound in Kanthapura the universal ideals of harmony, unity, oneness and selflessness. The village is a microcosm of the larger macrocosm of Greater India, rich in its cultural traditions and an unflinching unity running through the fabric of our society. It is his vision of oneness which drives the narrative in Kanthapura through the characters be it the evil Bade Khan or the gently seer Moorthy. The characters are the instruments through the action of the village, pulsating with life is brought to the fore. No character is particularly individualised. In this novel, what is lacking, and what infact constitutes the inherent charm, is this disinterestedness of the author with the doings of any particular individual. The reason we see the individuals not by themselves but rather acting at the behest and call of the wider design of national solidarity and freedom from foreign yoke is the central part being played by this unseen character of the village. Like a many coloured rainbow, we are made to feel the multidimensional character of village Kanthapura. There is plenty of ambivalence too in the characters, which round off their eccentricities. Range Gowda has a golden tongue and a leather tongue. His approval fetches elephants' howdahs and music procession: his disapproval forces people to eat bitter neem leaves and to eat humble pie. He is a terror to the authorities but a rescuer of his community. Rangamma presents a happy fusion of the discordant qualities: a widow with a gold belt and Dharamwar sari, associated with calf and cow and described as a tight-jawed person who could speak like a man. A soft-voiced and gentle-gestured woman 
imparts force and fervour to Moorthy's movement. She blends politics with religion, history and legends, and inspires chivalry among the home-ridden women, with the stories of the Rajput women, the heroic deeds of Kamla Devi, Sarojini Naidu and Annie Besant. Ratna is a "bangled widow". She runs like a boy. Her love for Moorthy develops into brother-sister relationship. She is called "shameless" and "wicked-tongued". She collaborates with Rangamma in mobilizing the Sevika Sangh in Moorthy's absence.

Bhatta is an outstanding example of insistencies. He is a money-minded priest more absorbed in material activities than in the pursuit of truth. He can marry a girl of his daughter's age, solemnize the marriage of gap-toothed Advocate with Venkamma's daughter, but frowns upon Ratna when she merely behaves like a married women. He can throw away his priestly duties but cannot put up with the modern ways of Ratna. Bhatta's business and pretensions expose contradictions in him and repudiate his plea for an exclusive religion and segregation of people into castes. He is split between his religious and mundane activities, between his pretensions and practice, between his self-interest and shallow anxiety for the welfare of the community. What waterfall Venkamma says about Rangamma, out of sheer prejudice applies to Bhatta:

"for land and lust and wifely loyalty go badly together, like oil and soap and hot water."

What he repudiates about himself is borne out by his actions. Moorthy is himself a synthesis of a cow and a holy bull, a squirrel and an eagle, a rat and a lion, a deer and a lion, a pebble and a small mountain.

Imagery, drawn from rural life, nature, history and mythology of India, come as a handy material with which to garb the village and characters. Kanthapura is "curled like a child on its mother's lap." It floats like a procession of the gods in the month of Kartik, as the procession of gods passes through the streets. Its revelry is like that of a marriage party. He describes its exploitation in 'being bled to death' and its mood of mourning over the arrest of Moorthy - "no man left his verandah, not a mosquito moved", and over the death of old Ramkrishnayya. Kanthapura's desolation is described thus: "there is neither man nor mosquito in Kanthapura." Bhatta is summed up in the images of a well-wisher of cows and men, butcher's son and the water of ocean which would be insufficient to wash his sins; Narsamma's dream and her misery, in bamboo and banana; Rangamma's graciousness, is as tame as a cow, her solicitude in a calf, her heroic qualities are presented in the picture of legendary women. Moorthy's concept of religion as a binding force finds expression in the image of procession, congregation or marriage or funeral parties and march; his concept of universal unity and harmony is pictured through a 'thousand-pillared temple', 'a sack of mustard seed', and 'being yoked to the same plough'; his concept of evil, in the lantana bush. He is described as cow, elephant, deer, lion, a holy bull, a sacred eagle and a small mountain.

Raja Rao's penchant lies in describing the simple village life of a remote village through the eyes of an observer who has laced his imagination in the deepest memories of the Indian sensibility. The absence of a central hero carrying the burden of the plot is symptomatic of his wider design to present the socio-cultural changes being brought to the Indian society through the agents of freedom and education. The conflict between the western ideals with the ancient Indian traditions had ushered in a new thirst of openness and questioning. What the Englishmen conspired to make the nation dependent upon Western thought and lifestyle resulted in the villages to wake up 
to the call of truth and self- reliance. What Gandhi preached was not something alien to the minds of the umpteen villagers. It was the basic ideals which had kept the fabric of Indian society together for centuries. The village as the hero of Kanthapura fulfils the desire of the novelist to present this very epitome of creative writing. Kanthapura thus is not only a novel. In the depiction of this simple village, the author highlights the outburst of sleeping giant - the giant of the Indian Renaissance responding to the call of the 'Mahatma'. The call is singular and clear. The country will awake, arise and stop not till the goal of freedom is achieved.

\section{References}

[1] Rao Raja : Kanthapura

[2] Ahmed Ali : Illusion and Reality - The Art and Philosophy of Raja Rao

[3] Mc Cutchion David : The Novel as Sastra

[4] Narasimhan Raja : Aspects of Indo-English Fiction

[5] Narasimhaiah C D : The Swan and the Eagle

[6] Iyengar Srinivas : Indians writing in English

[7] Parameswaran Uma : A study of Representative Indo English Novelists

[8] Ignatius Stephen Hemenway : Raja Rao's Kanthapura and The Serpent and the rope

[9] Verghese C Paul : Indian Writing Today

*Corresponding author.

E-mail address: cfri2005@rediffmail.com 